\title{
Adult Refugee Learners With Limited Literacy: NeEdS AND EfFective Responses
}

\author{
JOHN BENSEMAN
}

\begin{abstract}
Adult refugees with limited education are a distinctive learner group with substantial and distinctive educational, social, and psychological needs. Working with these learners is a highly specialized activity, requiring high levels of educational skill and commitment. With a paucity of original research available about this group of learners, this study provides a systematic documentation of their distinctive needs as well as effective educational strategies for use with these learners. The study involved interviews with 36 adult refugees, two program co-ordinators, five course teachers, and six bilingual tutors from a community-based program in New Zealand. The challenge of working with these learners arises due not only to their experiences as refugees, but also as learners with minimal or no educational experience. Their progress depends on a skilful development of "learning to learn," acquiring basic literacy skills, personal confidence and transfer of these skills to everyday life outside the classroom.
\end{abstract}

\section{Résumé}

Les réfugiés adultes peu scolarisés forment un groupe distinct d'apprenants ayant des besoins éducatifs, sociaux et psychologiques importants et particuliers. Travailler avec ces apprenants est une activité hautement spécialisée, qui exige des niveaux élevés de compétences éducatives et d'engagement. Étant donné le peu de travaux de recherche originaux disponibles sur ce groupe d'apprenants, cette étude fournit une documentation systématique de leurs besoins particuliers et présente des stratégies d'enseignement efficaces pour ces apprenants. L'étude a porté sur des entretiens avec 36 réfugiés adultes, deux coordonnateurs de programme, cinq enseignants et six tuteurs bilingues d'un programme communautaire en Nouvelle-Zélande. Travailler avec ces apprenants pose un défi non seulement en raison de leur expérience en tant que réfugiés, mais aussi en tant qu'apprenants n'ayant que peu ou pas d'expérience éducative. Leur succès dépend de leur habileté à "apprendre à apprendre", de l'acquisition de compétences de base d'alphabétisation, de la confiance en soi et du transfert de ces compétences à la vie quotidienne en dehors de la salle de classe.

\section{Introduction}

New Zealand accepts up to 750 refugees each year from around the world. Typically, these people are "the casualties of crises such as brutal regimes, civil war, anarchy and famine. Often, they are at risk because of their ethnicity, political beliefs or religion. They may have endured persecution, torture, rape or abduction, or have witnessed killings. Many arrive after perilous journeys and detention in refugee camps, having lost loved ones, homes, possessions and jobs." 1

Once they arrive in New Zealand, the refugees who have spent time in transit camps are initially inducted over a sixweek period into local life and introduced to refugee-focused NGOs and other settlement agencies at a refugee centre in Auckland. From here the new arrivals are dispersed around the country to centres usually chosen because there are already compatriots settled there. On reaching their new destination, a range of services (both government and voluntary) come into operation to help in the settlement.

Each new arrival is entitled to up to 100 hours of teaching with a government-funded provider. Typically, those with more education study at more formal institutions, while 
those with low-level skills attend courses run by community-based organizations.

\section{Research Purpose}

The purpose of this study was to document and analyze the learning needs and issues of adult refugees with low language and literacy skills by looking at how their prior experiences and current contexts affect their educational participation and learning. In addition, the study has sought to identify preferred educational strategies for teaching these learners. The specific focus of the study was adult refugee learners with low-level language and literacy skills (in English, but often also in their first or mother language (L1) currently enrolled in educational programs with a major communitybased provider.

\section{Related Research}

The quest to identify effective teaching methods has a long history in education but is much shorter in adult education. Historically, some adult educators have looked to philosophical models such as Paulo Freire and Malcolm Knowles, but most have relied on established traditions and variations of practitioner wisdom. More recently, however, there has been a move to emulate other professions and the schooling sector to base teaching practices on research findings. ${ }^{2}$ While there is a wealth of relevant research to draw on in schooling contexts, ${ }^{3}$ adult education has been less endowed, although this situation is steadily changing.

The intention with research-informed teaching is for practitioners to shape their practices in keeping with the best available research evidence, which maximizes the potential for learner impact, in contrast to operating on the basis of old habits and hearsay. Although the ideals of research-informed research inevitably give priority to "gold standard" large-scale, sophisticated quantitative studies to ensure generalizability of findings, smaller-scale qualitative studies are also recognized as having an important contribution to this approach, especially in opening up new areas, complementing quantitative studies, and offering valuable insights through their "thick descriptions" of subjects, contexts, and specific learner groups. It is in this regard that the present study is presented as a means of understanding effective teaching practices for adult refugee learners by exploring what a group of refugees in New Zealand and their teachers report as valuable and beneficial for them. While there is considerable general literature about refugees and their children, there is very little original research on adult refugees as learners or teaching them, especially in New Zealand.

\section{The Importance of English and Literacy Skills}

Some research evidence ${ }^{4}$ shows that becoming literate in the host country's language is essential for making friends outside refugees' own community, finding and sustaining employment, gaining secure income, as well as maintaining social and psychological well-being. The New Zealand Immigration Service ${ }^{5}$ reported that only $12-53$ per cent of refugees were working two years after arrival, usually parttime and still supplementing their income with government benefits. Refugees of all ages are therefore often identified as a high-need target group for educational interventions.

For those adults with minimal or no schooling experience, the need is primarily centred on their lack of literacy skills (including oral English), especially for those not literate in their first languages. Not being literate in one's first language has considerable implications for learning literacy skills in a second language. Researchers ${ }^{6}$ have shown that learning to read in a second language will invariably be difficult and slower: "Besides learning specific processing skills, a literate person learns to process information in ways qualitatively different from those of a non-literate person. Formal schooling provides particular skills, possibly used primarily in formal school settings, and the combination of thinking and performance skills is a reciprocal relationship that permits learning in a formal classroom setting."

In other words, the more education one has, the easier it is to learn all aspects of a new language. Learners who are reading for the first time in any language need to learn a range of reading-related skills such as interpreting figures, text organization, even oral discrimination, left-to-right orientation, associating symbols with objects, and picture interpretation. Once students have learned these sorts of skills, they can then be transferred to new languages, even if they vary significantly from the original one in which reading was taught.

\section{Educational Provision for Refugees}

A number of studies ${ }^{7}$ have detailed the overall shortfalls and inadequacies of educational provision for adult refugees in New Zealand. Their criticisms include not just the inadequacies of course availability, but also the irrelevance of the teaching content of many courses, with the potential to "create an underclass of refugees who subsequently experience significant direct and indirect discrimination."8 Some writers ${ }^{9}$ have also identified specific barriers that prevent or restrict refugees' enrolment and attendance at classes such as lack of child care, caring for family members, health issues, financial barriers, attending paid employment, transport difficulties, gender barriers, living in isolated areas, and understanding how "systems" work in order to access information and resources. 


\section{Learning Issues}

A government report on New Zealand English for Speakers of Other Languages (ESOL) $)^{10}$ acknowledged that "learning progress for pre-literate learners is extremely slow. Traditional assumptions about stair-casing to higher level programmes need to be challenged in the case of pre-literate learners." The report recognizes that these learners' needs are complex and require specialist resources and teaching approaches.

Invariably, most studies report the importance of understanding the psychological trauma that many refugee learners have endured prior to arrival in their new countries. Trauma can include physical and psychological torture, living in primitive conditions in transit camps for long periods, sustained separation from family and friends, and cultural alienation in their new host societies. One study ${ }^{11}$ identified three distinct types of stress that refugees face (migration, acculturative, and traumatic) that occur when the burden on people from external events or internal pressures on their lives exceeds their resources to cope.

An in-depth study of eight refugees and ten educators ${ }^{12}$ concluded that while it is important not to pathologize the effects that war and other catastrophes may have on learners, these factors should also not be underestimated as they come to grips with living in their new society. Even for less traumatized learners, "despite their supportive learning environment the students are suffering from loneliness, depression and lack of appropriate expert counselling, lack of legal and language rights and information and have few opportunities to speak English outside the class and to integrate with members of the host community."13

Magro therefore argues that resettlement issues cannot be separated from language development, and teachers should work from a broad definition of literacy that includes not only numeracy, problem solving, and the ability to read, write, and speak English, but also emotional and social literacies such as motivation, interpersonal effectiveness, critical thinking, and cultural awareness.

Some writers ${ }^{14}$ have pointed out that particular groups of refugees have greater or distinctive needs relative to others. These groups include older people, asylum seekers, those with physical disabilities, women, and youth (potentially a lost generation who feel they don't fit into either their original or their new country).

\section{Teaching Strategies}

There are few studies available on the teaching of adult refugees. In a study of Sudanese refugees in Australia, research$\mathrm{ers}^{15}$ found that speaking, listening, reading, writing, numeracy, and learning skills simultaneously may be too great a learning burden for these learners. They argue that there needs to be greater flexibility in course content and outcomes, so that learners can concentrate initially on oral English-language skills. They also conclude that the teaching of Sudanese refugees would work better with teachers with relevant background information on Sudanese students, classes reduced to 10 students, and Sudanese learners being taught separately from other learners.

With regard to this last point, an English report ${ }^{16}$ identified a successful program for traumatized refugees in Sweden who would normally have dropped out of mainstream ESOL provision. The course integrated educational needs with the learners' physical and psychological needs. The course evaluation concluded that traumatized refugees need to be identified early and be given special support, as those who have failed in other courses have little chance of successfully learning Swedish.

A New Zealand evaluation ${ }^{17}$ of the impact on ESOL learners has also demonstrated better results for those who were taught using bilingual tutors, compared with those taught by English-speaking tutors. Results were also better for those with greater educational experience and who had longer periods of teaching. An evaluation ${ }^{18}$ of five refugee programs also reported the value of "ethno-specific learning" and having bilingual support. These programs achieved very high rates of student retention (up to 100 per cent) and learner motivation, with the greatest impediments being child care and transportation difficulties.

There has also been criticism ${ }^{19}$ of the teaching skills of some ESOL teachers working with low-skill refugees with limited English skills. These writers have recommended greater professionalism, increased professional development (especially about working with low-level learners), and greater access to cross-cultural training and information and translated materials. A New Zealand survey of immigrant learners ${ }^{20}$ reported that many were dissatisfied with the lack of translators, the high course costs, and the lack of opportunities to practise their English.

Finally, in terms of the teaching content for refugee programs, $\mathrm{McDermott}{ }^{21}$ reported that most refugees aspire to independence in their daily lives, such as daily tasks of shopping and visiting their doctor. An English study of seven asylum-seekers ${ }^{22}$ found that this group of students wanted some key things in their courses: greater independence and control in contrast to their past lives, integration into family networks, and communities and emotional support.

\section{Methodology}

This study was undertaken in co-operation with a large community-based ESOL provider. Two sites were chosen for the study because of their reasonable accessibility and the ready availability of suitable interviewees. From a potential 
Figure 1. Living locations of interviewees $(\mathrm{n}=36)$

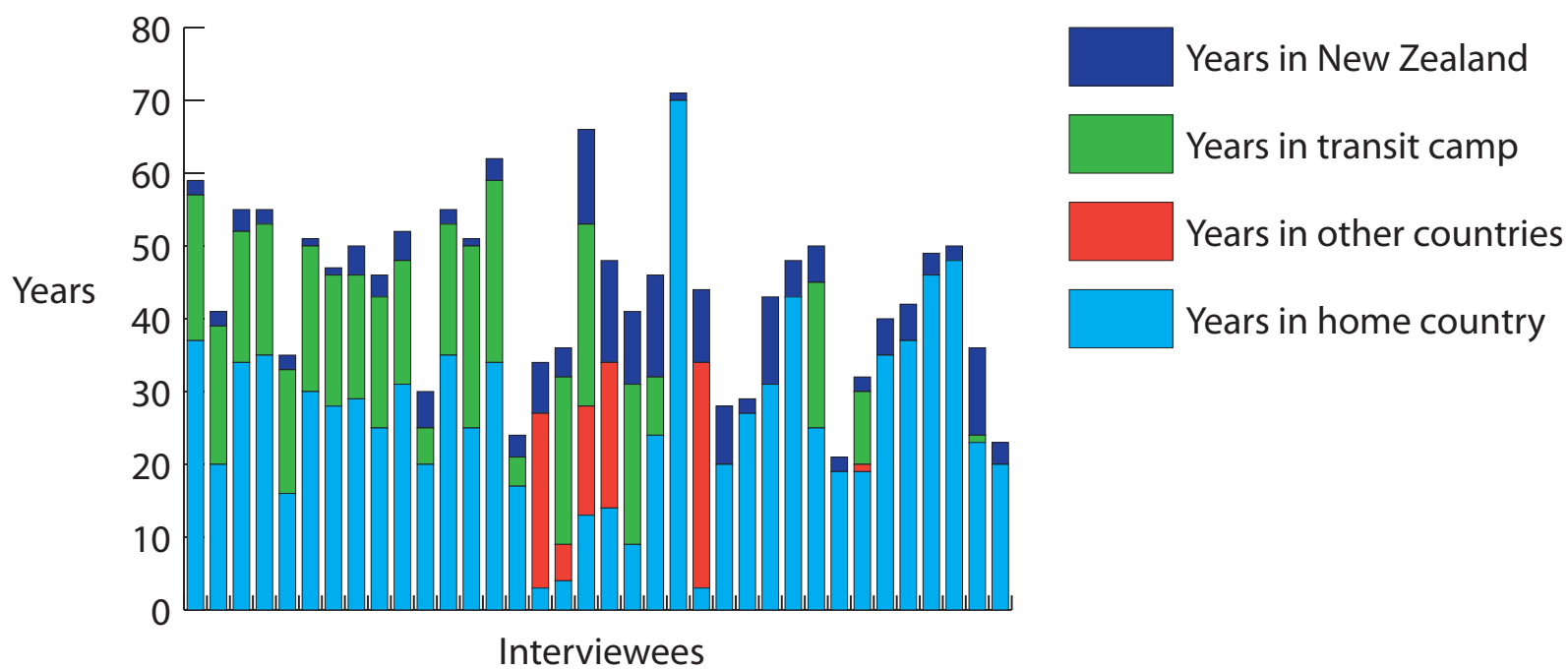

Source: Interviews of respondents

total of approximately 140 refugees in the two areas, a sample of 36 were chosen who had completed enough tuition and were knowledgeable and confident enough to provide feedback, could be accessed during site visits, and had first languages in common to make interpretation in groups possible. The learners were originally from Bhutan, Burma, Sri Lanka, Afghanistan, Ethiopia, Pakistan, India, Iran, Iraq, Kuwait, and Palestine. Interviews were held with program co-ordinators (two), course teachers five) and bilingual tutors (six).

Of the 36 learners interviewed, 29 were women and 7 were men. Their average age was 44.2 years, ranging from 71 years to 21 years. The great majority were married, with four widowed (all in their home countries), one was divorced, and four were single. All had at least some family in New Zealand, including grandparents, siblings, and grandchildren. Of those who had children, the average number of children per interviewee was just over two. Five said that they had sons or daughters still either in their home country or in North America.

Figure 1 indicates where the interviewees had spent their lives. It shows the low number of years spent in New Zealand (4.9 years), but also how variable their experiences are in relation to transit camps. Overall, they had spent an average of 15.3 years in camps. A third had not been in camps at all, although they may have spent some time in other countries before coming to New Zealand.

The learners were interviewed in focus groups (of three to five) to provide a supportive environment among compatriots. Teachers and bilingual tutors (BLTs) were interviewed individually. In addition to the responses to a series of set questions asked of all interviewees, extensive notes were taken during the interviews by the interviewer, especially in relation to the open questions and additional information offered in the course of answering set questions. The set question responses were analyzed in terms of simple frequencies, while the interview notes were examined and analyzed for additional information and themes. Each interviewee had a consent form explained orally via interpreters, and all signed it prior to the interviews.

\section{Course Description}

The 36 learners were spread over six classes held at five different venues. The classes had 20-26 learners, with new learners still joining as the courses progressed; in one course, six new learners had joined in the past week. All classes had a tutor and a bilingual tutor who worked alongside the course teacher. Most learners attended a total of 10 hours each week (usually over four sessions).

The teaching content of the courses was broadly set by a curriculum constructed by the provider organization but also incorporated suggestions from the learners themselves and from current issues and needs. In most cases, learners were recruited through social workers or contacts in their own communities. There were consistent comments that course attendance was unfailingly high as a result of high levels of motivation. 


\section{Findings}

\section{Learners' Perspectives}

The 36 learners came from 10 different countries, speaking a number of second and third languages in addition to English. Their diversity extended to a range of religious backgrounds, castes, and settlement journeys en route to New Zealand. The great majority had not attended any schooling in their home country, which means that most were not literate in any language, including L1. A few had attended school for up to three years and a smaller number had attended up to eight years. This latter group could read and write to a low level in their L1.

Their journeys from their homeland to New Zealand varied considerably. Some had spent many years in transit camps, while others had come directly to New Zealand as part of a family reunification process. The trauma ${ }^{23}$ they had experienced also varied considerably; in one group, most of the men had been imprisoned and in some cases, tortured. Some of the women in this group had been raped. Those who had been in transit camps had faced many years of uncertainty about their future, social dislocation from family and friends, resentment from local people, and prolonged periods of inactivity and uncertainty while they awaited decisions about their future settlement. The effects of this internment often had long-term effect on these refugees: poor health (chronic conditions that recur periodically, as well as long-term disabilities from severely broken bones, for example), neurological dysfunction (demonstrated by high levels of anxiety in unfamiliar settings such as the classroom), and feelings of alienation in their new setting. One BLT commented that one of the most enduring negative effects of living in transit camps is a deep-seated feeling of dependency, because they were unable to work or provide their daily necessities of living, as these were provided by those running the camps.

\section{English and Literacy Skills}

Only a few had any English prior to arriving in New Zealand. Some had picked up some English during their time in transit camps, but this occurred largely on an informal basis. Teachers commented that those starting the course with some English tend to have very little comprehension and operate on a "word-by-word translation" model of speaking.

About a third of the group had been attending a literacy course for six months or less, another third for approximately 6-18 months, and a third for two years or more. Several others said that they had dropped out of classes in the past and had attended other classes before enrolling in the current one. They had dropped out mainly because they found the classes too difficult or because of domestic issues.
Several had had their attendance interrupted because they had moved around within New Zealand.

Asked what they wanted to achieve by attending their class, all expressed slight variations on learning enough English to be able to carry out daily tasks, whether it be shopping, speaking to their neighbours, or making enough progress to enrol in a higher-level course. Underpinning all their replies was a strong desire to achieve personal independence so that they did not have to rely on their children, spouse, or a third party in order to do things such as talk to their doctor or their children's teachers. This desire was expressed by both men and women and especially by the older interviewees. About half said that they wanted to get a job, although most realized that this was a long-term goal, given their current level of English. Several older men said that while health issues precluded being able to hold down a full-time job, they would like to volunteer their time in the community. Other aims included having enough English to help support their children to finish school and to help them achieve what they want to do, to understand what their children were saying to their friends, to read street names, to identify food items when shopping, to get a driver's licence (mainly women), and to solve problems for their family.

\section{Feedback on Courses}

The interviewees were asked their opinions of the current course they were attending. The responses were unanimously positive, with specific mentions of their teachers, the BLTs, the program, the location, the timing of the class, being able to practise their English, various aspects of the teaching (such as repeating words until memorized), achieving particular skills (for example, being able to write their name and address, using a bus, talking on the phone, using an ATM, using the Internet), and the personal support they had received since arriving in New Zealand. Many mentioned the positive value of having a BLT involved in their class.

Asked if there were any aspects of the course they did not like or would like changed, only a few identified any issues. These criticisms included the inclusion of children in some classes because of the noise, not taking a break in the middle of their lesson, the crowded conditions in the classroom and transport difficulties.

They were also asked if the course had helped them achieve their personal goals. Most responses to this question were positive, giving examples of tasks they were now able to do because of the skills that they have learned on the course-as one learner said, "It's helped a lot. I knew nothing before coming to class. Now I can go shopping on my own and pay my bills. I can take my wife to the hospital for 
her appointments without an interpreter." Another said, "I can recognize my street name now when I see it and I greet people on the way to class." Most of these achievements were of an immediate nature, helping them function on a daily basis more easily, while longer-term achievements like getting a job they saw as aspirational and dependent on achieving greater fluency and confidence in English and literacy skills.

The interviewees were all asked what they found their greatest challenges as learners. Many were unable to articulate specific challenges or said that they had no problems. Most of the challenges mentioned related to learning processes: not being able to hear sounds, speaking, retaining new learning, spelling English words, and not understanding word meanings. Other challenges related to wider issues: lack of time to practise amid a busy family life, feeling tired, homesickness, depression, lack of access to the teacher because there were large numbers in the class, constant new arrivals, sight problems, and coping with family members' health issues.

\section{Teachers}

All five course teachers also taught non-refugee classes but had been chosen for the current course specifically for their expertise in teaching low-level literacy to refugees. One manager commented that they had to carefully proceed when selecting and introducing new teachers. Even some of their experienced ESOL teachers had not lasted in the refugee classes, as they were unused to the slow progress. In some cases, using inappropriate teachers had meant losing both the teacher and learners.

All teachers were female and had formal teaching qualifications, some of which was at postgraduate level. They had an average of over 13 years ESOL teaching experience, ranging from 4 to 25 years. Most had also done some ESOL home tutoring, and several had extensive experience teaching in schools, including one person with more than 40 years' experience. All had been involved in teaching refugees for more than 2 years, with some having up to ten years' experience.

Asked what they wanted to achieve with their current class, all tutors said that they aimed for some fluency in basic conversational English language skills for everyday living, especially to help them solve their learners' problems and challenges and thereby achieve greater independence. While all mentioned oral skills as their prime aim, some also specified literacy aims such as writing and reading. Several pointed out that this aim was quite basic in most cases, because the learners also had limited literacy skills in their first language. In some cases, it involved discerning initial word sounds, learning motor skills for forming letters, learning a new alphabet, recalling previous learning, understanding the direction of text, understanding new word orders and learning to listen, analyze, and reflect, using questions. As one teacher said, "It takes awhile for some of them to understand the difference between a question and an answer, let alone getting them to start asking questions or responding to them."

Alongside this aim, all mentioned wanting to provide an introduction to successfully living in the New Zealand environment. Other aims mentioned included gaining general confidence, achieving a sense of accomplishment, and feeling welcome and supported.

They were then asked what they felt constitutes success in the light of these aims. Here, several teachers talked about the importance of seeing changes in how their learners perceived themselves: "If they are happy, engaged in their learning, and realizing that they can have success, they can do more than before." Another teacher looked for changes in specific patterns of interaction: replying when asked a question, remembering from previous lessons, being able to discern all the words in a sentence, understanding the correspondence between words and sounds, using written prompts for speaking, and transferring learning into new words. One teacher looked for changes in how learners participated in their community and especially in family life where there were often parents with no English and where there was a strong reliance on children whose language skills had developed more strongly than the adults'. Gaining confidence in English in these cases helped restore the confidence and feelings of selfworth of the learners as parents within their family.

\section{Teaching Challenges}

As all of the teachers had experience teaching ESOL with non-refugees, they were asked what differences they noticed in teaching refugees compared with other ESOL classes. Several mentioned the effects of psychological trauma on their ability to learn (usually in terms of poor attention spans and "nervous energy"), dealing with dislocated families where some family members were still in dangerous situations, and general homesickness, but the most frequent comment related to their low levels of literacy skill, which meant that they had to "learn to learn," picking up many basic skills (for example, establishing routines, setting goals, interpreting symbolic representations such as maps and diagrams, dealing with abstractions, sitting at a table, appropriate rules of behaviour, following instructions, using glue) that teachers take for granted in other ESOL classes. As one teacher said, "You have to start learning from the absolute beginning. You can't take anything for granted." Other differences included very low levels of ambition "because they don't know yet what they can do." 
With such low levels of basic learning skills, teachers found that learners were not able to work on tasks independently (either at home or in the classroom) as they were reluctant to ask for help, or if they did, found it hard to specify their difficulty. They also felt that refugees took longer to retain new learning. One very experienced teacher said she estimated that her refugee learners took four to five times longer to consolidate their new skills than other ESOL learners.

Other challenges were probably not unique to refugee learners, but were present nonetheless. For example, because of traditional perceptions of teachers and their high initial dependency, most learners tended to see their teachers as experts to be revered, the sole source of learning, and particularly one who imparts knowledge. This "teacher as expert" perception made it difficult to initiate learner-centred activities where learners were encouraged to function as part of small groups, where they provided mutual help and support, or where individual learners were set independent tasks. Several teachers commented that learners found it difficult to work in this learner-centred way initially, but gradually became comfortable with it over a period of months. New learners then joining the class often joined in more readily, because current class members helped socialize them into these new activities.

Teachers reported no difficulties with recruitment or attendance. The only difficulties with attendance were due to what teachers saw as valid reasons such as religious celebrations, bad weather (having to walk long distances to class), and coping with family crises and illness.

\section{Learning Gains and Wider Impact}

All the teachers agreed that most of the learners' gains were small and incremental. One very experienced teacher explained, "Progress is slow and variable. It varies according to things like age and their previous education. Young learners with some schooling make much faster progress than older ones who have never been to school. Some take four to give years to get to a point where they are confident and comfortable with 'survival English' and can leave the class, but there's always pressure to get into jobs."

In terms of impact outside the classroom, the teachers had varied viewpoints. One of the younger teachers was cautious about their progress: "It's hard to say. They say that they are more relaxed and competent, but it's slow progress." Others were more confident that their learners were making progress, mainly because the course content was strongly influenced by the learners generating their own topics of current interest or need. One commented, “They are more confident. It broadens their outlook and makes New Zealand a little more familiar and comfortable." Another who worked mainly with women was more adamant: “There's been a visible improvement. They can make themselves understood, they have better access to health services because they can communicate with doctors and so on with increased confidence and higher self-esteem."

\section{Use of BLTs}

As the use of BLTs was an integral part of teaching these courses, the teachers were asked for their assessments of this strategy. Their responses were universally positive. They valued their BLTs for a range of reasons: acting as a role model, helping identify and resolve issues in learners' wider lives, providing instant clarification of language-related difficulties, providing help in small-group work, acting as an intermediary generally between the tutor and learners, picking up subtle cultural signals from learners, motivating and affirming individual learners, and helping organize class events and outings. BLTs were also key to coping with large classes.

There were also a number of difficulties or limitations with the use of BLTs in some cases: restrictions when the BLT did not speak some of the learners' languages, limitations when a few BLTs themselves had limited English skills, and a danger that some learners become dependent on the BLT translating when they should be working harder to understand things themselves.

Finally, the tutors were asked for any general reflections about what they had learned as a result of teaching their refugee course. One tutor said that working with such lowlevel learners had "made me think a lot more deeply about my teaching and had broadened my teaching skills." Several tutors commented that working with refugees had made them more sensitive to cultural issues, giving them greater understanding of cultural barriers, both inside and outside the classroom (especially the discrimination they face): "It's taught me how to meld different cultures together and about tragedy and dislocation." Another commented, "You can never assume they see things the same way as you do," and that "even if their progress can be slow, everyone will learn, even the elderly."

\section{Bilingual Tutors}

Six bilingual tutors were interviewed; they originally came from Bhutan, Afghanistan (two), Ethiopia, and Iran (two). Most spoke at least three languages and had learned at least some English in their home country, usually at school. Several had also attended English-language classes in transit camps. Most were reasonably fluent in English to a level where they freely conversed in their interviews. Two were a little hesitant and struggled to express themselves at times. Formal qualifications ranged from none to a $\mathrm{PhD}$. All had 
completed a two-day bilingual certificate course and had variable experience as teachers, either in schools or with adults.

\section{The Role of the BLT}

Asked how they saw their role as BLTs, all mentioned supporting and assisting the class tutor in a collaborative way. They identified a range of ways they do so: interpreting and explaining for the learners, facilitating communication generally, explaining cultural customs to the tutor, and working with individual learners on tasks set by the tutor. All the BLTs were clear that the teaching agenda was set by the class tutor and that it was the role of the BLT to help achieve the tasks specified by the tutor: "She explains what she wants and I translate, work with the students, making sure they know what to do."

As one recently recruited BLT explained, "It's important to make the students feel safe-they know there will be someone who can explain." Another said, "[It's about] filling the gap, working like a bridge, explaining when they don't understand either in English or [L1]." This BLT said that it was important that the BLT shared the background of the learners with the tutor in order to explain why they did or didn't do things, as most of the learners had never been to school and didn't always understand what was expected of them.

Asked to reflect on their experiences as BLTs, all were unanimous about it being a positive experience. Several said that the role could be frustrating at times, mainly as a result of the learners' difficulties in achieving their goals.

The BLTs named two key outcomes for the learners: improving their language skills in order to become independent, and overcoming cultural barriers in order to integrate into New Zealand society and achieve healthy lifestyles in their new environment: "[It's great] every time a learner achieves their own small goal, maybe writing their name, go shopping, or whatever."

\section{Challenges for BLTs}

The BLTs named particular challenges they found working with low-level refugee learners: coping with constant influxes of new learners, working with large classes, often in confined spaces, multi-level classes, identifying what learners need help with, clarifying instructions, giving due attention to single learners whose L1 is different from others' in the class, coping with the different ethnic groups in the class where these groups had very different values, achieving progress with older learners, and difficulties in completing tasks outside the classroom. There were also mentions of factors outside the classroom such as transport, financial difficulties, looking after relatives with serious or o-going illness, lack of child care, and issues involving their children.

The BLTs consistently mentioned the importance of gaining confidence, not only in English language and literacy skills, but also the confidence to try these new skills outside the classroom. The most valued act of independence for both men and women to be able to visit health practitioners without having to have someone (especially one of their children) accompanying them to interpret.

\section{Effective Practices}

All those interviewed for this study were asked to identify factors or strategies they believed helped refugee learners learn English and literacy skills in their context. Each group offered different assessments, but they also shared many of the following list in common:

\section{Teaching Strategies and Skills}

- Constant revision of previous learning to ensure consolidation

- Varying teaching strategies according to the needs and skills of the learners

- Ready access to support in L1 with BLTs, especially for very low-level learners

- Importance of everyone experiencing success by matching teaching to learners

- Being responsive, looking for opportunities to maximize learning with individuals

- Approaching tasks from different ways to ensure relevance; rephrasing and re-presenting if not successful

- A cycle of modelling/acting/role-play/re-cycle/reflection/practise in pairs

- Ensuring that learners with a common language can work together

\section{Teacher Qualities}

- Patience

- Understanding that learners' previous trauma can be played out in the classroom

- "Being human" and demystifying the "teacher as expert"

\section{Teaching Content}

- Ensure that learners have all the requisite "learning blocks" to build higher levels of learning

- Ensure relevance of teaching content by using realia of everyday life tasks and issues

- Importance of teaching all four literacy skills (reading, writing, listening, and speaking)

- Importance of basic sight words taught every day

- Phonics, especially for low-level learners 
- Rote practice of oral skills, especially with very lowlevel learners, to ensure a solid foundation of key foundation skills

\section{Teacher Development}

- The need for ongoing professional development, including BLTs

\section{Learning Environment}

- Creating and sustaining a welcoming, supportive environment

- Carefully grouping of learners within the classroom to ensure cultural values are respected

\section{Interpersonal Relationships}

- Importance of believing they can succeed (self-efficacy) through praising achievement

- Showing respect for learners in relation to their age (especially older men), religion and culture

- Understanding that learners' previous trauma can be played out in the classroom in the form of constant headaches, difficulties in concentrating on tasks, and ongoing health issues

\section{Outside the Classroom}

- Practising new skills outside the classroom

- Field trips to significant New Zealand sites

- Pastoral care for issues outside the classroom

\section{Discussion}

The challenges teachers face in achieving impact with their adult refugee learners come primarily from two main sources: the social and pedagogical background of the learners and the nature of the content being taught. In both these respects, ESOL literacy courses for refugees present considerable challenges for the tutors involved.

While they do have diverse backgrounds and experiences, many refugee learners also have much in common that constitutes a considerable challenge for their teachers, especially in order to achieve the impact they might normally expect in their classrooms. As this study and the review of the related research literature has shown, many refugees have encountered different types of trauma as a result of being exiled from their home country, undertaking a long and complicated transit through refugee camps and intermediary countries, before starting the gradual adaptation to their new environment. It is difficult to definitively assess the impact these experiences have on refugees generally and in relation to learning in particular, but it is clear that these learners bring much to the classroom that is not always immediately discernible that can impede and delay their rate of progress, compared with other learners.

Added to these psychological constraints, the great majority have had at best minimal schooling experience and in most cases, none at all. As adult learners they therefore lack the "learning blocks" that most learners acquire as schoolchildren and teachers take for granted. Knowing how to behave appropriately in a classroom is not inherent behaviour, so for refugees "learning" starts with fundamental skills as basic as holding a pen, discerning between questions and answers, and learning to work co-operatively on set tasks with their fellow pupils. In addition, they need to comprehend the intrinsic nature of literacy itself-that written symbols represent sounds, words, and meaning. In order to do this, they may need to learn a new alphabet and different directional conventions about how English writing is presented on the page.

Even with these basic learning skills underway, most refugee learners begin acquiring their English and other literacy skills at the lowest level, as they have no, or minimal, previous English and they often lack reading and writing skills in their first language. With all of these factors in play, progress is usually slow and painstaking, requiring the teacher to carefully scaffold skills, building on the small steps previously achieved, and constantly revising in

Figure 2. Wheel of progress

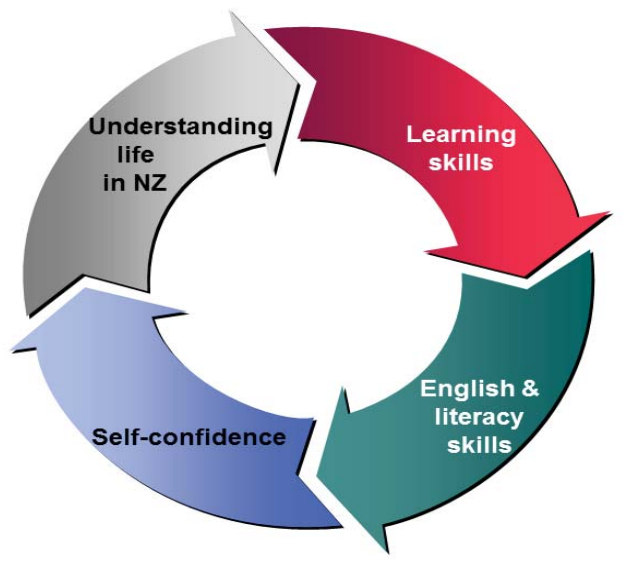

order to consolidate these initial gains. Making progress in language and literacy skills is developed through a balance of contextual learning to ensure personal relevance and motivation, but also the teaching of structural aspects of language to ensure correct guidelines for English usage.

As the learners develop their learning skills and fundamental literacy skills, they also develop a set of skills, attitudes, and knowledge about their new environment, enabling them to undertake daily tasks in their community 
with increasing confidence. These gradual developments in turn build self-confidence, which in turn helps develop the motivation to further develop their language and literacy skills. The self-confidence that comes from achieving learning milestones is also augmented by affective elements resulting from a supportive learning environment. All these components combine to provide a positive momentum, which gathers force as the different factors mutually reinforce each other. This wheel of progress (see figure 2) is extremely difficult to turn initially, but can gain momentum with skilful exertion on the four components.

There are inevitably impediments to achieving this momentum. Psychological factors resulting from the refugee experience provide resistance that are unseen but unquestionably present in the learners' abilities to take on new skills in an unfamiliar environment. External factors relating to managing families' crises, coping with scant resources, and a lack of knowledge and familiarity about support mechanisms and services can also impede what happens in the classroom. At worst, open discrimination exacerbates a feeling of anomie in surroundings that are vastly different from what they left behind. Within the classroom, crying babies, crowded conditions, and high and increasing roll numbers also counter what the teaching staff can achieve.

It is difficult to know the extent and specific impact of these strategies on refugees' learning outcomes without substantial studies involving classroom observation and pre- and post-assessment of their skills. Nonetheless, they constitute a valuable pointer to what refugees value in the classroom and what teachers and their bilingual assistants rate as effective.

\section{Notes}

1. "Who Are Refugees?," Encyclopedia of New Zealand, http://www.teara.govt.nz/en/refugees/1.

2. John Benseman, Research-Informed Teaching of Adults: A Worthy Alternative to Old Habits and Hearsay?, Unitec ePress Occasional and Discussion Paper Series 2, 2013, http:// www.unitec.ac.nz/epress/wp-content/uploads/2013/02/ RBT-Article-Final.pdf.

3. See, for example, John Hattie, Visible Learning: A Synthesis of over 800 Meta-analyses Relating to Achievement (London: Routledge, 2009).

4. Strategic Social Policy Group, Diverse Communities: Exploring the Migrant and Refugee Experience in New Zealand (Wellington: Ministry of Social Development, 2008).

5. New Zealand Immigration Service, Refugee Voices: A Journey towards Re-settlement (Wellington: Department of Labour, 2004), 32.
6. Martha Bigelow and Robin Schwarz, Adult English Language Learners with Limited Literacy (Washington DC: National Institute for Literacy, 2010), 9.

7. Judy Altinkaya and Helen Omundsen, "Birds in a Gilded Cage: Resettlement Prospects for Adult Refugees in New Zealand," Social Policy Journal of New Zealand 13 (1999): 31-42; Alison Gray and Sue Elliott, Refugee Resettlement Research Project "Refugee Voices" Literature Review (Wellington: New Zealand Immigration Service, 2001); Kevin Roach and Anneliese Roskvist, "ESOL Provision for Adult Immigrants and Refugees in New Zealand: Policy, Practice and Research," Prospect 22, no. 3 (2007): 44-63; Teachers of English to Speakers of Other Languages Aotearoa New Zealand, "Refugees Learning English (2003), http://www .tesolanz.org.nz/Site/Publications/Reports/Refugees_2003 .aspx.

8. Altinkaya and Omundsen, "Birds in a Gilded Cage," 7.

9. Ibid.; Gray and Elliott, Refugee Resettlement Research Project; Kevin Roach and Anneliese Roskvist, "ESOL Provision for Adult Immigrants and Refugees in New Zealand: Policy, Practice and Research," Prospect 22, no. 3 (2007): 44-63; Teachers of English to Speakers of Other Languages Aotearoa New Zealand, "Refugees Learning English (2003)"; Noel Watts, Cynthia White, and Andrew Trlin, English Language Provision for Adult Immigrants and/or Refugees from Non-English-Speaking Backgrounds in Educational Institutions and Private Training Establishments in New Zealand (Palmerston North: Massey University, 2001); Cynthia White, Noel Watts, and Andrew Trlin, Immigrant and Refugee Experience of ESOL Provision in New Zealand: Realities and Responsibilities (Palmerston North: Massey University, 2001).

10. Tertiary Education Commission, English for Speakers of Other Languages: Reports on National Gaps and Priorities (Wellington: TEC, 2008), 6.

11. Myrna Adkins, Barbara Sample, and Dina Birman, Mental Health and the Adult Refugee: The Role of the ESL Teacher (Washington, DC: National Center for ESL Literacy Education, 1999).

12. Karen Magro, "Overcoming the Trauma of War: Literacy Challenges of Adult Learners," Education Canada 47 (Winter 2006-7): 70-4.

13. Michael Baynham, Priti Chopra, Melanie Cooke, Rachel Hodge, Kathy Pitt, Celia Roberts, Philida Schellekens, Cathering Wallace, and Shelley Whitfield, English for Speakers of Other Languages (ESOL): Case Studies of Provision, Learners' Needs and Resources (London: National Research and Development Centre, 2004).

14. Altinkaya and Omundsen, "Birds in a Gilded Cage"; Gray and Elliott, Refugee Resettlement Research Project; Natasha McMillan and Alison Gray, Long-term Settlement of Refugees: An Annotated Bibliography of New Zealand and International Literature (Wellington: Department of Labour, 2009); Amritha Sobrun-Maharaj, Samson Tse, Ekramul Hoque, and Fiona Rossen, Migrant and Refugee Youth in 
New Zealand: A Study of Key Informants (Wellington, DC: Department of Labour, 2008).

15. Ursula Burgoyne and Oksana Hull, Classroom Management Strategies to Address the Needs of Sudanese Refugee Learners (Adelaide: National Centre for Vocational Education and Research, 2007).

16. David Barton and Kathy Pitt, Adult ESOL Pedagogy: A Review of Research; An Annotated Bibliography and Recommendations for Research (London: National Research and Development Centre, 2003).

17. Nikhat Shameem, Keryn McDermott, Jeannie Martin Blaker, and Jenny Carryer, Through Language to Literacy: A Report on the Literacy Gains of Low-Level and Pre-Literate Adult ESOL Learners In Literacy Classes (Auckland: UNITEC, AUT and ESOL Home Tutor Service, 2002).

18. Keryn McDermott, Review of Adult Refugee Education Programmes (Wellington: Ministry of Education, 2004).
19. Watts, White, and Trlin, English Language Provision for Adult Immigrants; Teachers of English to Speakers of Other Languages Aotearoa New Zealand, "Refugees Learning English (2003)."

20. White, Watts and Trlin, Immigrant and Refugee Experience.

21. McDermott, Review of Adult Refugee Education Programmes

22. Michael Baynham et al., English for Speakers of Other Languages (ESOL).

23. The trauma experiences of the participants were not a focus of this study. Information about these experiences was offered voluntarily in the course of the interviews, but was mainly reported by the teachers or BLTs.

John Benseman is an associate professor in the Department of Education at Unitec Institute of Technology. The author may be contacted at john.benseman@criticalinsight.co.nz. 